того - готовність їх сприймати і застосовувати на виробництві, тобто прагнути до професійної мобільності. На нашу думку, саме так слід розуміти поняття «професійна мобільність»: це не тільки професійне зростання, прагнення до саморозвитку, а ще й відкритість до сприйняття нової інформації, бажання покращити виробничі показники, виготовляти якісну продукцію чи надавати якісні послуги.

Отже, сучасний ринок праці потребує висококваліфікованих професійномобільних фахівців з розвинутою креативністю, здатних критично мислити і тих, що мають когнітивні здібності. Саме професійна мобільність фахівців дає можливість максимально ефективно використовувати результати підвищення кваліфікації фахівців будь-якої галузі.

1. Грибова Л. В. Організаційно-методичні засади підвищення кваліфікації фахівців сфери туризму: дис. ... кандидата пед. наук: 13.00.04. / Грибова Людмила Володимирівна. - Вінниця, 2010. - 181 с. 2. Гринько В. О. Емпіричне дослідження складових професійної мобільності викладача вищої школи / В. О. Гринько // Збірник наукових праць КПНУ імені Івана Огієнка, Інституту психології ім. Г. С. Костюка НАПН України // Проблеми сучасної психології. - 2011. - Вип. 14. - С. 134-143. 3. Добрышина Е. В. Профессиональная мобильность как один из критериев качества образования [Электронный ресурс]/ Е. В. Добрышина. - Режим доступа : http://h.kubstu.ru/juk/vipusk6.htm 4. Наказ Міністерства праці та соціальної політики та Міністерства освіти і науки України «Про затвердження Положення про професійне навчання кадрів на виробництві» від 27 березня 2001 року № 127/151 5. Сорокин П. А. Социальная мобильность // Человек. Цивилизация. Общество/ Общ. ред. сост. и предисл. А. Ю. Согомонова. - [пер. с англ.]. - М. : Политиздат, 1992. 543 с. 6. Професійна мобільність як сучасна педагогічна проблема [Текст]/ Л. Л. Сушенцева // Креативна педагогіка : наук.-метод. журнал. - 2011. - Вип. 1. С. 129-136. 7. Професійна освіта: Словник: [навч. посіб.] / Уклад. С. У. Гончаренко та ін.; за ред. Н. Г. Ничкало. - К. : Вища школа, 2000. - 380 с.

УДК 372.461

Артур Іншаков

\title{
ДІЯЛЬНІСНИЙ ПІДХІД ДО ОРГАНІЗАЦІЇ СЛОВНИКОВОЇ РОБОТИ З ДІТЬМИ СТАРШОГО ДОШКІЛЬНОГО ВІКУ
}

Іншаков А. Є. Діяльнісний підхід до організації словникової роботи 3 дітьми старшого дошкільного віку.

У статті розкрито шляхи реалізації діяльнісного підходу до організації словникової роботи 3 дітьми старшого дошкільного віку. Схарактеризовано мовленнєву діяльність дошкільнят під час формування й поглиблення словника. Наведено зразки вправ, які сприяють збагаченню словника дошкільнят у процесі художньо-мовленнєвої діяльності.

Ключові слова: діяльнісний підхід, діти дошкільного віку, словникова робота, мовленнєва діяльність, художньо-мовленнєва діяльність.

Иншаков А. Е. Деятельностный подход к организации словарной работы с детьми старшего дошкольного возраста.

В статье раскрыты пути реализации деятельностного подхода к организации словарной работы с детьми старшего дошкольного возраста. Охарактеризована речевая деятельность дошкольников при формировании и углублении словаря. 
Приведены примеры упражнений, которые способствуют обогащению словаря дошкольников в процессе художественно-речевой деятельности.

Ключевые слова: деятельностный подход, дети дошкольного возраста, словарная работа, речевая деятельность, художественно-речевая деятелньность.

Inshakov A. Y. Activity approach to the organization of the dictionary work with children preschool age.

The article deals with the realization of the activity approach to the organization of the dictionary work with children of preschool age. Speech activity of preschool children in the formation and deepening of the vocabulary is characterized. The examples of exercises that contribute to the enrischment of vocabulary of preschool children in the process of artspeech activity are given.

Key words: activity approach, preschool children, dictionary work, speech activity, artistic speech activitie.

Грунтовний аналіз чинних програм навчання та виховання дітей дошкільного віку, огляд сучасних методичних розробок засвідчують, що робота з розвитку словника дітей дошкільного віку цілеспрямовано проводиться у процесі регламентованого навчання, обмежуючись завданнями конкретного заняття, без тісного взаємозв'язку 3 подальшою мовленнєвою роботою, закріпленням словникового запасу, активним його застосуванням дітьми в щоденній мовленнєвій практиці.

Проблема розвитку словника дошкільнят є досить складною та багатоаспектною, тому розв'язанню ii присвячено роботи психолінгвістів, лінгвістів, педагогів, методистів, дефектологів (А. Арушанова, А. Богуш, О. Гвоздєв, Л. Калмикова, Л. Колунова, Г. Ніколайчук, Ф. Сохін, В. Тищенко, М. Шеремет). Фундаментальні загальнонаукові положення проблем лексикології виявляють системні взаємозв'язки в лексиці та їі зв'язки з іншими рівнями мови (О. Ахманова, В. Виноградов, В. Звегінцев, О. Потебня, А. Уфімцева, Д. Шмельов).

Організація словникової роботи має враховувати різні наукові підходи як до вивчення, так і власне до практики. Визначення діяльнісного підходу до організації словникової роботи в дошкільних навчальних закладах конституюється на фундаментальних положеннях, які полягають у тому, що: 1) розвиток словника відбувається в мовленнєвій діяльності, що супроводжує інші види діяльності; 2) процес засвоєння словника має діяльнісну природу.

Mema cmammi- розкрити механізм словникової роботи 3 дітьми старшого дошкільного віку з позиції діяльнісного підходу.

Провідною діяльністю дошкільників (Д. Ельконін, О. Запорожець, В. Котирло, С. Ладивір, Н. Михайленко) є гра. У провідній діяльності виникають і в подальшому диференціюються нові види психічної діяльності, що створює умови для переходу до наступного етапу. Крім цього, саме в ній перебудовуються також часткові, окремі психічні процеси. Провідною діяльність $є$ не стільки стосовно інших видів діяльності (кожна з яких має певне значення для розвитку), скільки стосовно формування новоутворень як основних психологічних змін в особистості на кожному етапі онтогенезу.

Діяльність впливає на поведінку дитини, і в ній реалізуються цілеспрямовані дії. Водночас діяльність пов'язана 3 пізнавальними та вольовими процесами, розглядається як внутрішня (психічна) і зовнішня (фізична) активність людини, що регулюється усвідомлюваною метою. У діяльності важливою є наявність мотиву й 
усвідомлюваної мети (Л. Виготський, С. Рубінштейн) [4; 8].

Мовленнєва діяльність має аналогічну структуру до іншої діяльності (постановка мети, планування і здійснення плану, зіставлення мети й результату). Мовленнєва діяльність дитини безпосередньо пов'язана з навчанням, а фізіологічною основною навчання дитини $є$ утворення довгих рядів і складних систем умовних рефлексів як взаємозв'язок зовнішніх і внутрішніх подразників [3].

Мовленнєва діяльність посідає особливе місце серед різних видів діяльності. У межах психолінгвістичного підходу (І. Зимня, О. Леонтьєв) [6; 7] мовленнєва діяльність визначається як процес використання мови для спілкування під час будьякої іншої людської діяльності; специфічний вид діяльності (деяка абстракція), що не співвідноситься безпосередньо 3 пізнавальною, ігровою й навчальною діяльністю. Мовленнєва діяльність у формі окремих мовленнєвих дій обслуговує всі види діяльності; має місце за умови, коли мовлення є самоцінним, коли мотив, лежить в іiі основі і спонукає іiі, не може бути задоволений іншим способом, окрім мовленнєвого.

Отже, мовленнєва діяльність може визначатися як цілком самостійна діяльність зі специфічною мотивацією, при цьому її складниками є мовленнєві дії, що мають за мету підпорядкованість загальній меті діяльності; мовленнєві операції (різні, відповідно до умов) або мовленнєві дії, що входять до складу інших немовленнєвих дій. Структура мовленнєвої діяльності охоплює мовленнєвий акт, мовленнєву ситуацію, які повинні стати предметом їх подальшого розвитку.

Основою мовленнєвої діяльності є мова, водночас і вона, і мовленнєва діяльність тісно пов'язані між собою, зумовлюють одна одну, оскільки мова $є$ необхідною, щоб мовлення було зрозумілим і результативним, з іншого боку, мовлення необхідне, щоб сформувалася мова.

Мовленнєва діяльність визначається взаємодією трьох чинників - знанням одиниць мови та правил іiї сполучення, навичками користування цими одиницями та правилами, комбінаційним умінням використовувати наявні знання для вираження нової думки в новій ситуації (І. Зимня) [5, с. 11].

Розвиток мовлення дитини опосередковано навчанням: дитина навчається говорити, проте це цілком не означає, що оволодіння мовленням, рідною мовою $є$ в цілому результатом спеціальної навчальної діяльності, мета якої для дитини становить вивчення мовлення. Дитина оптимально оволодіває мовленням, навчається говорити, послуговуючись мовленням у процесі спілкування, який організовується дорослим так, щоб був результат - оволодіння мовленням. Навчальна діяльність, у якій ставилася б спеціальна мета - оволодіння мовлення, виділяється результатом, а не метою.

Навчально-мовленнєва пізнавальна діяльність реалізується через організацію і проведення мовленнєвих занять. У сучасній дошкільній лінгводидактиці методичні аспекти мовленнєвих занять достатньо розроблено (А. Богуш) [2]. Визначальною лінією пропонованих пізнавальних занять - збагачення уявлень дітей про довкілля, а розвиток словника забезпечує ефективність цієї роботи, водночас досягається зворотній ефект, оскільки активні процеси сприйняття різноманітного наочного матеріалу ігрові дії допомагають дітям осмислити значення слів і словосполучень. Актуальним є питання 3 виховання інтересу до слова дошкільників, поважного ставлення до власного мовлення, що становить умову розвитку словника.

Одним із видів мовленнєвої діяльності $є$ художньо-мовленнєва діяльність, тобто діяльність, пов'язана зі сприйманням літературних творів, виконанням їх, відтворенням, супроводжується образним, виразним мовленням, словесною творчістю (А. Богуш) [1]. Ключовими напрямами в організації художньо-мовленнєвої діяльності $\epsilon$ розвиток 
художньо-естетичного сприймання та словесної творчості; розвиток мовлення, виховання культури мовлення; літературознавча підготовка; збагачення емоційно-чуттєвого, когнітивного досвіду. Змістовою стороною художньо-мовленнєвої діяльності $\epsilon$ формування різних видів компетенцій: художньо-мовленнєвої, когнітивно-мовленнєвої, виразно-емоційної, поетично-емоційної, оцінно-етичної, театрально-ігрової.

Організація роботи над розвитком словника дітей старшого дошкільного віку є ефективною за тематичними групами («Я», «Мої іграшки», «Довкілля», «Пори року», «Улюблені казки» тощо; розроблення тематичних словничків у межах означених груп. Упродовж організації роботи 3 поглиблення словника дітей дошкільного віку має забезпечуватися послідовність етапів розвитку словника дітей (занурення, орієнтація, диференціація, активне вживання) 3 дотриманням пріоритетності індивідуальних форм словникової роботи над загальногруповими.

Проілюструємо найтиповіші вправи та ігри, що сприяли розв'язанню навчальних завдань розвитку словника.

\section{Вправа «Поясни вислів»}

Мета: удосконалювати навички старших дошкільників у розумінні прямого та переносного значення слів.

Тематична група: пори року.

Осінь принесла золотисті стрічки

Ростуть над ставком дві берези. Стрункі, високі, білокорі. Опустили берези зелені коси. Віє вітер, розчісує їх. То вони про щзось розмовляють.

Однієї ночі стало холодно. На траві заблищали білі кристалики льоду. Прийшла до беріз осінь. Принесла їм золотисті стрічки. Вплели берези стрічки в зелені коси. Зійшло сонце. Розтопило кристалики льоду. Подивилося сонще на берези й не впізнало ї - y зелених косах золоті стрічки. Сміється сонечко, а берези сумують (За В. Сухомлинським).

Словник: іменники: осінь, зима, весна, літо, лід, берези, сонце, ставок, коси, стрічки;

дієслова: рости, віяти, шелестіти, розмовляти, заблищати, розтопити, сміятися, розчісувати, зійти, розтопити, сумувати;

прикметники: стрункий, високий, білий, зелений, білий, білокорий, золотистий.

Матеріал для впровадження: ілюстрації з зображенням різних пір року.

Вид діяльності: художньо-мовленнєва.

Отже, як свідчить аналіз результатів виконання дітьми завдань, дошкільникам значно легше зрозуміти пряме, ніж переносне значення слів.

\section{Показник: ініціативність слововживання}

Мовленнсва вправа «Квіти»

Мета: збагачувати словник дітей іменниками (назвами квітів), прикметниками, дієсловами.

Тематична група: квіти.

Словник: іменники: квіти, кульбаба, волошки, троянда, чорнобривці, хризантеми, бузок, букет, екібана, жоржини;

дієслова: цвітуть, пахнуть, поливати, садити, зрізати, дарувати, складати, ходити, збирати, нюхати;

прикметники: польові, кімнатні, пахучі, декоративні, квітучі, гарні, яскраві, великі, весняні.

Матеріал для впровадження: ілюстрації квітів.

Виді діяльності: художньо-мовленнєва.

Хід вправи. Вихователь пропонує дітям пригадати назви квітів. Діти назвали 
троянду, гвоздику, деякі називали «кімнатні рослини». Після цього педагог читає вірші про тюльпан, дзвіночок, троянду, волошки, кульбабу, пропонує визначити про яку квітку вірш, як її описує автор.

Результатами виконання мовленнєвої вправи «Квіти» $є$ такі результати: діти вивчають і запам'ятовують назви квітів, описують квіти так, як описуються у віршах, намагаються розповідати про квіти, які вони бачили, описати їх. Словник старших дошкільників багатий на іменники: квіти, кульбаба, волошки, троянда, чорнобривиі, хризантеми, бузок, букет, жоржини; дієслова: цвітуть, пахнуть, поливати, садити, зрізати, дарувати, складати, ходити, збирати, нюхати; прикметники: польові, кімнатні, пахучі, декоративні, квітучі, гарні, яскраві, великі, весняні.

\section{Гра «Відгадай квітку»}

Вихователь читає оповідання В. Сухомлинського, пропонує уявити, про яку квітку йдеться в оповіданні; якби ви були метеликом, то якого кольору?.

\section{Як метелик плавав у ставку}

Летів білий метелик над ставком. А хтось кинув у воду червону квітку. Пливе квітка. Побачив метелик червону квітку. Сів на неї, сидить, крильиями водить. Квітка пливе, і метелик пливе.

Летить ластівка над водою, дивується: «Що це таке? Як метелик навчився плавати?» Доторкнулась ластівка крилом до води. Сколихнулась вода, сколихнулась квітка, загойдався метелик. Весело йому пливти в ставку. (За В. Сухомлинським)

\section{Вправа «Відгадай загадки»}

Мета: формувати уявлення старших дошкільників про переносне значення слів, активізувати словник дітей за темою «Пори року».

Тематична група: «Пори року».

Словник: іменники: осінь, зима, весна, літо, сніжинка, ковзани, кульбаба, метелик, хурделиця, листопад;

дієслова: опадати, падати, літає, шурчить, жовтіє, засніжило, кататися, розважатися, збирати, припікає;

прикметники: сонячний, дощова, морозний, зелений, теплі, веселий, жовтогарячий, білосніжний, пухнастий, барвистий.

Матеріал для впровадження: загадки.

Вид діяльності: навчально-мовленнєва.

Хід вправи. Педагог загадує дітям загадки: - Не крізь двері, а в вікно входить весело воно (сонце). Як ви гадаєте, що це таке? А чому про сонечко сказали «входить»? У якому значенні вжито це слово? Сиві коні полетіли і собою землю вкрили (туман). Хто такі сиві коні? Це - туман, правильно. Як ще можна про це сказати? На що схожий туман? (Молоко, димову завісу).

Крім навчання розуміння й пояснення переносного значення, дітей вправляли у формуванні синонімічних та антонімічних рядів.

Вихователь пропонував дітям відгадати ще одну загадку: Без рук, без ніг, а звалив оборіг (вітер). Про вітер говориться в прямому чи переносному значенні?

Педагог пропонував дітям пригадати як називають потужний вітер, що має силу перевертати кораблі, рушити будівлі. (Ураган). А морський сильний вітер? (Шторм). А вітерець міг би звалити оборіг? Чому?

Якщо дітям важко самостійно без навідних запитань відгадувати загадки, варто поглибити роботу над образними висловами.

Ефективним є аналіз міні-описів пори року, що сприяє розвитку естетичного порогу дітей старшого дошкільного віку: 


\section{Перший льодок}

Вчора ввечері на ставку хлюпотіли хвилі. А сьогодні мороз: ставок узявся першим льодком. Тоненький, прозорий льодок. А під ним плаває маленький карасик. Пливе карасик, хоче глянути на берег, а льодок не пускає. Дивується карасик: "Що ие таке?» (За В. Сухомлинським).

Організацію словникової роботи в дошкільному навчальному закладі варто організовувати у межах діяльнісного підходу, виходячи 3 того, що мовленнєва діяльність, у контексті якої розглядається словник, є специфічним видом діяльності; засвоєння словника неможливе поза діяльністю; збагачення словника найбільш ефективно відбувається у процесі навчально-мовленнєвої та художньо-мовленнєвої діяльності.

\section{Література}

1. Богуш А. М. Компетентнісний підхід у процесі професійної підготовки / А. М. Богуш. - К., 2009. - С. 231-239. 2. Богуш А. М. Мовленнєвий компонент дошкільної освіти / А. М. Богуш. - Одеса, 2004. - 176 с. 3. Богуш А. М. Мовленнєвий розвиток дітей від народження до 7 років: [монографія] / А. М. Богуш. - К. : Видавничий Дім «Слово», 2004. - 376 с. 4. Выготский Л. С. Воображение и творчество в детском возрасте / Л. С. Выготский. - СПб. : Союз, 1997. - 95 с. 5. Зимняя И. А. Педагогическая психология : [учебник для студентов вузов] / И. А. Зимняя. - М. : Логос, 2000. - 383 с. 6. Зимняя И. А. Упреждающий синтез и вероятностное прогнозирование в речевом поведении / И. А. Зимняя. - М. : Педагогика, 1973. - 215 с. 7. Леонтьев А. Н. Избранные психологические произведения / А. Н. Леонтьев. - М. : Педагогика, 1983. - Т. 1. - 391 с. 8. Рубинштейн С. Л. Основы общей психологии / С. Л. Рубинштейн. - СПб. : Питер, 1999. - $720 \mathrm{c}$.

\section{МОДЕЛЬ ПСИХОЛОГО-ПЕДАГОГІЧНОГО СУПРОВОДУ ФОРМУВАННЯ ЦІЛІСНОСТІ ОСОБИСТОСТІ У ПРОЦЕСІ ПРОФІЛЬНОГО НАВЧАННЯ}

Кельнер C. C. Модель психолого-педагогічного супроводу формування цілісності особистості у процесі профільного навчання.

У статті на основі теорії і практики наведено систему роботи щодо формування соціально-психолого-індивідуальної готовність учня до профільного навчання, запропоновано схему складників цієї готовності, визначаються шляхи й засоби, що сприяють процесу становлення цілісної особистості.

Ключові слова: соціально-психолого-індивідуальна готовність, інтелектуальна готовність, едукаційна готовність, рефлексивна готовність, мотиваційна готовність, комунікаційна готовність, особистісна готовність.

Кельнер С. С. Модель психолого-педагогического сопровождения формирования целостности личности в процессе профільного обучения.

В статье на основе теории и практики представлена система работы по формированию социально-психолого-индивидуальной готовности ученика к профильному обучению, предложена схема составляющих этой готовности, определяются пути и средства, способствующие процессу становления целостной личности.

Ключевые слова: социально-психолого-индивидуальная готовность, интеллектуальная готовность, эдукационная готовность, рефлексивная готовность, мотивационная готовность, коммуникационная готовность, личностная готовность. 